\title{
Managing Legitimacy in Complex and Heterogeneous Environments: Sustainable Development in a Globalized World
}

\section{Andreas Georg Scherer, Guido Palazzo and David Seidl} University of Zurich; University of Lausanne; University of Zurich

\begin{abstract}
The sustainability problems with regard to the production, distribution, and consumption of goods and services increasingly challenge the legitimacy of corporations. The literature distinguishes three strategies that corporations commonly employ to respond to legitimacy problems: adapt to external expectations, manipulate the perception of their stakeholders, or engage in a discourse with those who question their legitimacy. We discuss three approaches to determine the appropriate response strategy: one-best-way approach, contingency approach, and paradox approach. We argue that in the face of heterogeneous environments with conflicting demands, corporations that follow a paradox approach are likely to be more successful in preserving their legitimacy than those that adopt one of the other two approaches. We develop a theoretical framework for the application of different response strategies and explore the management of paradoxes by way of structural, contextual, or reflective means.
\end{abstract}

Keywords: corporate legitimacy, corporate responsibility, globalization, institutional theory, paradox, sustainability

\section{INTRODUGTION: SUSTAINABLE DEVELOPMENT AND GORPORATE LEGITIMAGY}

The United Nations World Commission on Economic Development (WCED) defines sustainable development $(\mathrm{SD})$ as the 'development that meets the needs of the present without compromising the ability of future generations to meet their own needs' and suggests that this 'should become a central guiding principle of the United Nations, Governments and private institutions, organizations and enterprises' (United Nations, 1987). SD rests on three principles: environmental integrity, social equity, and economic prosperity (Bansal, 2005; Marcus and Fremeth, 2009). In its recent analysis of the current state of the planet, the WWF (2012) has shown that human development is unsustainable. The globalization process intensifies problems such as global

Address for reprints: Andreas Georg Scherer, University of Zurich, Universitätsstr. 84, CH-8006 Zurich, Switzerland (andreas.scherer@uzh.ch). 
warming, chemical pollution, ocean acidification, water scarcity, and biodiversity loss (Rockström et al., 2009). Since these problems manifest themselves as negative sideeffects of business activities occurring along globalized systems of production and consumption (Buckley and Ghauri, 2004), '[t]he legitimacy of business has fallen to levels not seen in recent history' (Porter and Kramer, 2011, p. 64). Legitimacy can be understood as the social acceptance of business organizations and their activities and is considered a vital resource for organizations (Ashforth and Gibbs, 1990). While the business world was initially reluctant to assume responsibilities for SD (Bansal, 2002; Hedstrom et al., 1998), the growing societal sensitivity to unsustainable business practices has motivated corporations to engage with the SD discourse. Therefore, many corporations have adopted sustainability principles as part of their mission statement in order to respond to legitimacy concerns (WBCSD, 2012).

The globalization process has changed the institutional environment of global business and the way corporations can maintain their legitimacy. In a globalized world the regulatory power of the nation-state governance system is in decline (Beck, 2000; Cutler, 2001; Kobrin, 2001) and cultural homogeneity within social communities is eroding due to processes of migration and individualization (Beck, 2000; Beck-Gernsheim and Beck, 2002). Under these conditions, which have been referred to as the post-national constellation (Habermas, 2001), the power to address issues of public concern, to define standards for behaviour, and to determine the conditions under which SD can unfold is shifting from state institutions to private actors (e.g., business firms) and civil society actors (e.g., NGOs and social movements) (Chandler and Mazlish, 2005; Kobrin, 2001; Mathews, 1997; Mena and Palazzo, 2012). As a result the corporate environment has become highly complex and ambiguous (Child and Rodrigues, 2011; Jones and Fleming, 2003; Smith and Lewis, 2011). Under these conditions corporations have difficulties in maintaining their legitimacy (Kobrin, 2009; Kostova and Zaheer, 1999; Scherer and Palazzo, 2007). Legitimacy strategies such as simply adapting to the environment (isomorphic adaptation) or manipulating the perceptions of the most important social constituencies (strategic manipulation) do not work as smoothly as they once did (Oliver, 1991). In a globalized world, accepted standards of behaviour, such as legal rules or self-regulation schemes (Shelton, 2000), are often fragmented or not available (Fischer-Lescano and Teubner, 2004), so that the corporation has to engage in a process of moral reasoning where it is initially not clear whether the corporation or the societal expectations will dominate the resolution, or a new position will be created (Palazzo and Scherer, 2006; Suchman, 1995).

Building on the SD discourse, we challenge two assumptions about legitimacy. First, despite the often significant conceptual differences, the scholarly debate treats legitimacy as a general perception about the corporation as such (Greenwood et al., 2011), while we argue that legitimacy results from a variety of often parallel and contradictory perceptions of the corporation with regard to specific SD issues - ranging from environmental issues such as water scarcity to social issues such as working conditions in supplier factories. We suggest that dealing with SD-related legitimacy issues is particularly challenging when operating in fragmented and dynamic global environments with a multitude of complex and often contradictory sustainability demands.

Second, theoretical assumptions behind the different approaches - such as the resource-based view (Christmann, 2000; Hart, 1995), institutional theory (Bansal, 2005; 
Delmas, 2002; Schaefer, 2007), or discourse ethics (Palazzo and Scherer, 2006) - are so contradictory that the discussion gives the impression that corporations have to choose one general legitimacy strategy from the three options, i.e. manipulation, adaptation, or moral reasoning (Palazzo and Scherer, 2006; Suchman, 1995). In contrast, we will argue that corporations have all three options at their disposition and the appropriate choice depends on the particular issue at stake. Particularly in fragmented and dynamic global environments, which face a multitude of complex and often contradictory sustainability demands, there is no 'one-best-way', but corporations are left with the 'paradox' (Smith and Lewis, 2011) of enacting all three strategies simultaneously. The literature offers insights into the different approaches to managing response strategies, especially in complex environments (Child and Rodrigues, 2011; Pache and Santos, 2010; Simsek, 2009). However, the combination of legitimation strategies and their organizational prerequisites has yet to be explored (see, e.g., Bednarek, 2011; Greenwood et al., 2011; Lamin and Zaheer, 2012). Therefore, we address two research questions: First: What strategies do corporations possess for dealing with SD-related legitimacy challenges and when are these implemented? Second: How can corporations deal with contradictory sustainability demands requiring conflicting legitimacy strategies?

We will explore the corporate responses to environmental demands and will argue that the legitimacy strategies of corporations are influenced mainly by two factors: the cost of organizational change, and the heterogeneity of environmental demands. However, in complex global environments corporations face multiple legitimacy challenges at the same time, making it necessary to respond to these challenges simultaneously by employing several response strategies, rather than by focusing on one comprehensive legitimacy strategy for the entire organization (see, e.g., Child and Rodrigues, 2011). In the literature there are three approaches to analyse corporate responses: the one-best-way approach, the contingency approach, and the paradox approach. We argue that in the face of increasingly complex and heterogeneous SD-related demands, corporations that employ a paradox approach, enabling them to switch between or to employ simultaneously the three different legitimacy strategies, are likely to be most successful in preserving their legitimacy. Other than the one-best-way approach or the contingency approach, this allows corporations to choose the most suitable response strategy for each specific legitimacy challenge rather than having to stick to one response strategy for all legitimacy challenges. Yet, as we will show, such a paradox approach is quite demanding, as it requires a capacity to handle the inherent contradictions between the different response strategies. We will discuss the respective structural, contextual, and reflective preconditions (Schreyögg and Sydow, 2010) implied by such a capacity.

While the aim of this study is purely descriptive in the sense that we explore what makes some corporations more successful than others in preserving their legitimacy in complex environments, the argument could easily be turned, also normatively, in the sense that if corporations want to be successful in that respect, they should follow the described paradox approach. Yet, we would like to abstain from such a normative turn as this would require a more elaborate discussion of wider normative-ethical concerns (Palazzo and Scherer, 2006) which is beyond the scope of this paper.

The paper is structured as follows. In the next section we will address our first research question by discussing the different legitimacy strategies and developing a framework for 
the management of corporate legitimacy in complex environments. This will be further elaborated in the third section where we will present anecdotal evidence of how corporations employ the different legitimacy strategies. In the fourth section we will address our second research question and discuss potential approaches ('one best way approach', 'contingency approach', and 'paradox approach') for selecting legitimacy strategies in complex environments with heterogeneous sustainability demands. We will elaborate on the paradox approach as the most promising and outline the preconditions for accommodating such an approach within the organization. We conclude with a reflection on the contributions of this study.

\section{MANAGING GORPORATE LEGITIMAGY IN COMPLEX ENVIRONMENTS: A FRAMEWORK}

Legitimacy can be understood as the social acceptance of actions or institutions and is ascribed to corporations in processes of social construction (Ashforth and Gibbs, 1990). Legitimacy is vital to corporations as it is a precondition for the continuous flow of resources and for securing the sustained support of the organization's constituencies (Pfeffer and Salancik, 1978). Legitimacy of corporations is challenged when their actions are perceived as inappropriate and undesirable within their respective societal contexts (Palazzo and Scherer, 2006; Suchman, 1995). Suchman (1995) argues that organizational legitimacy can rest on the benefits that are perceived to spring from the organization's existence or behaviour (pragmatic legitimacy), or on the - often subconscious - acceptance of the organization, its structures, and processes, as representative of a 'normal' status quo (cognitive legitimacy), or on an explicit moral discourse about the acceptability of the organization and its activities (moral legitimacy). In the literature, the relationship between the corporation, legitimacy, and SD has been explored with a focus on the pragmatic and cognitive perspective. Pragmatic legitimacy has been explored from a resource-based theory (Barney, 1991) and cognitive legitimacy from an institutional theory perspective (Meyer and Rowan, 1977). Resource-based theorists emphasize the business case for SD (Orlitzky et al., 2011; Shrivastava, 1995; Siegel, 2009) and argue that certain resources and capabilities help corporations realize higher economic rents by contributing to SD (Christmann, 2000; Hart, 1995). From this perspective, corporations either provide economic benefits to their constituencies or engage in impression management in order to maintain their legitimacy. Institutional theorists, in turn, suggest that corporations strive for societal approval and respond to institutional pressures by adapting to SD principles (Bansal, 2005; Delmas, 2002; Jennings and Zandbergen, 1995; Schaefer, 2007).

Business firms are considered legitimate when their organizational practices are perceived to satisfy the social expectations of their environment. Normally, capitalist institutions such as business firms, property rights, contractual obligations etc. meet general expectations about modern society, and do not raise legitimacy concerns unless everyday routines fail or there is a crisis. Within the capitalist system, economic institutions and processes are routinized and unfold within the established and socially accepted legal rules of the economic game. As long as these taken-for-granted institutions and processes 


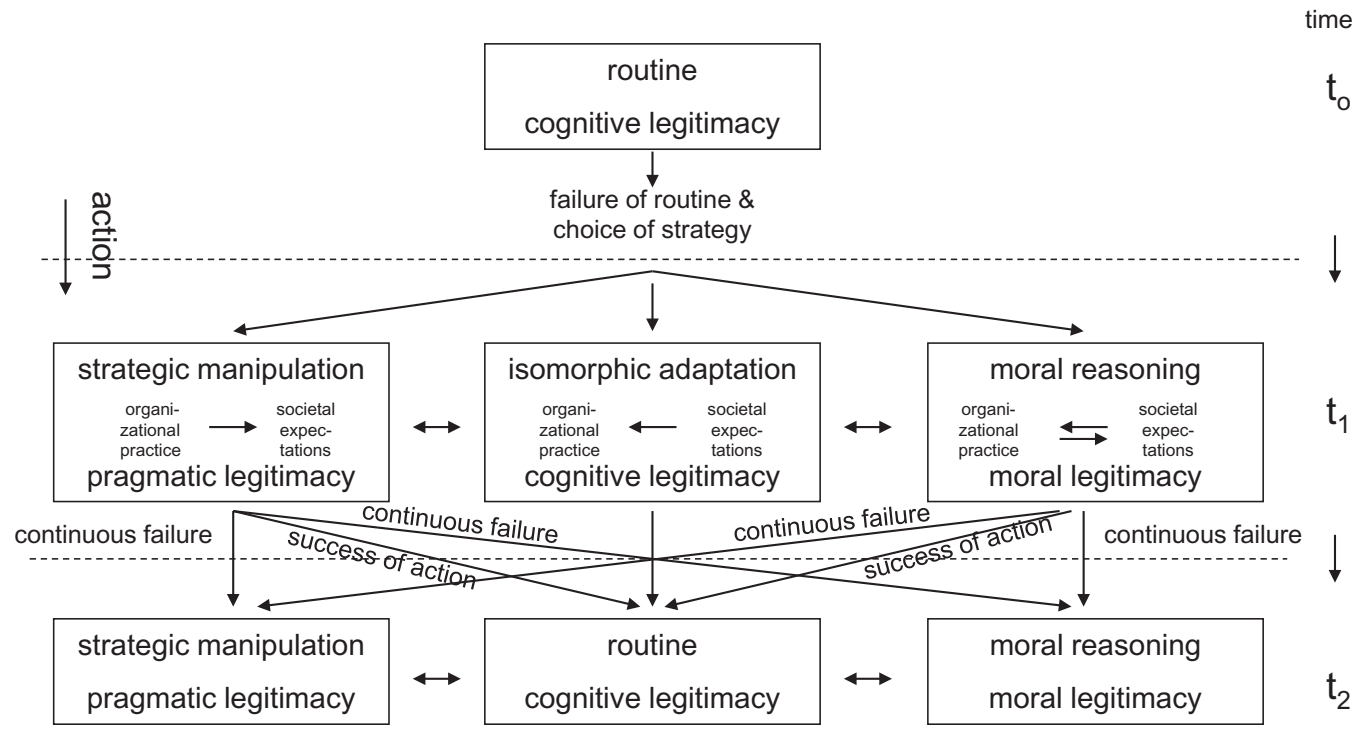

Figure 1. Strategies of corporate legitimacy

do not fail and are not questioned, they build upon cognitive legitimacy. This legitimacy is disputed if social actors perceive a mismatch between the corporation's status-quo and societal expectations (see Figure 1).

The post-national constellation will make such a situation more likely, as in the global arena multinational corporations (MNCs) operate under conditions of governance gaps resulting from global public goods problems (Kaul et al., 2003), incapable or unwilling national governments (Kobrin, 2001), insufficient regulatory power of international organizations (Beck, 2000; Habermas, 2001), and a lack of acceptable and coherent standards of behaviour (Chandler and Mazlish, 2005).

We suggest that, logically, corporations have three different legitimacy strategies at their disposal to (re)establish the congruence between their organizational practices and societal expectations, summarized in Figure 1 (Oliver, 1991; Palazzo and Scherer, 2006; Suchman, 1995): the isomorphic adaptation strategy, the strategic manipulation strategy, and the strategy of moral reasoning. The isomorphic adaptation strategy means that corporations can change their organizational practices and adapt to societal expectations in order to maintain cognitive legitimacy (Deephouse, 1996). In Figure 1 this is indicated by the arrow in the isomorphic adaptation box, which points from societal expectations to organizational practice. Such a scenario might arise when corporations change their practices to meet the interests and legitimacy concerns of their most powerful stakeholder groups (Mitchell et al., 1997).

The strategic manipulation strategy describes cases where corporations actively influence social expectations by swaying or even manipulating the perceptions of key actors or policy-makers in their environment (Barley, 2010; Child and Rodrigues, 2011; Oliver, 1991). The notion of 'manipulation' refers to 'the active attempt to alter the content of institutional requirements and to influence their promoters' (Pache and Santos, 2010, 
p. 463). Here, societal expectations are mainly shaped by the corporation's political strategy (Hillman et al., 2004), which in Figure 1 is indicated by the respective arrow in the strategic manipulation box. The corporation attempts to influence these expectations through advertising campaigns, the dissemination of (mis)information, lobbying, and other instruments of strategic public relations and impression management (Barley, 2010; Fombrun, 2001; Oliver, 1991).

The third strategy, that of moral reasoning, builds upon a process of deliberation. The organization engages in an open discourse with focal stakeholders or societal groups in order to argue for the acceptability of its status quo and behaviour (Habermas, 1990; Scherer and Palazzo, 2007). Both parties consider the pros and cons of their positions and try to find a common solution that is based on a sound argument and serves the well-being of society rather than egoistic motives or narrow interests. This mode of interaction 'reflects a pro-social logic that differs fundamentally from narrow self-interest' (Suchman, 1995, p. 579). Unlike persuasion strategies, which aim to establish one’s own position by manipulating the other party's position, moral reasoning means that the two parties try to learn from each other and eventually adapt their positions constructively. The aim is to reach a consensus (or at least an informed compromise) and ultimately a new match between organizational practices and societal expectations that will (re)establish legitimacy (Palazzo and Scherer, 2006).

The key difference between the moral, adaptive, and manipulative strategies of legitimacy lies in their respective assumptions about the locus of control. While the manipulative view puts forward that the corporation can influence how its key constituencies perceive its legitimacy, the adaptive view builds on the assumption that the corporation is subject to the control of surrounding institutional pressures and routines. The moral legitimacy view, in turn, argues that legitimacy results from the discourses that connect organizations with their environment. Whether these legitimacy strategies are mutually exclusive and whether they could or even should be combined has yet to be resolved (Bednarek, 2011; Lamin and Zaheer, 2012).

Corporations opt for either the isomorphic adaptation strategy or the manipulation strategy primarily in order to maintain their legitimacy. Occasionally, these strategies are complemented or even substituted by moral reasoning. In line with the economic and institutional approaches, we expect that the particular choice of legitimacy strategy can be explained on the basis of two factors: (a) the costs of organizational change, i.e. the costs incurred by making necessary changes to a corporation's structure and processes so that they match societal expectations and contribute to sustainable development (Hart, 1995; McWilliams et al., 2006); and (b) the consistency of societal expectations to which the corporation has to respond when attempting to (re)establish its legitimacy. The latter factor draws on institutional theory (Greenwood et al., 2011; Pache and Santos, 2010; Powell and DiMaggio, 1991) and the theory of paradox (Poole and Van de Ven, 1989; Smith and Lewis, 2011).

(a) A failure of organizational routine that reduces the social acceptability of a corporation and its behaviour will incur costs in the form of time, labour, and assets that are necessary in order to resolve the misfit between organizational practice and societal expectations. In order to respond to sustainability issues that are put 
forward by societal stakeholder groups, corporations have to rearrange their value chains (e.g., stop sourcing from countries with undemocratic regimes), change their production processes or product technologies (e.g., implement green technologies), or spend resources (e.g., invest in infrastructure and public goods such as public transportation, education, or security in host countries where public authorities are not able or willing to do so) in order to preserve the natural environment or protect human rights. The cost dimension is emphasized by the theory of the firm perspective on CSR: corporations invest in corporate sustainability and protect their legitimacy as long as the benefits exceed or at least equal the costs (McWilliams and Siegel, 2001; Orlitzky et al., 2011; Siegel, 2009; Springle and Maines, 2010). Likewise, resource-based theory argues that corporations may achieve a favourable position in competition when they develop specific competences to pursue a sustainability strategy (Barney, 1991; Christmann, 2000; Hart, 1995). For other corporations such competences represent an entry barrier and overcoming this incurs costs.

(b) MNGs have extended their activities to countries and cultures that have different societal and institutional conditions. As global actors, they are exposed to two contradictory pressures. On the one hand, globalization promotes a transnational standardization of rules and (mainly soft law) regulation (Brunsson et al., 2012; Gilbert et al., 2011). On the other hand, the diversity of local contexts in which MNGs operate creates institutional contradictions: 'the globalization of practices and cultures increasingly exposes organizations to the simultaneous influence of local and global institutional pressures. Local regulative, cognitive, and cultural influences interfere with national and global trends toward homogenization of rules, values, and practices' (Pache and Santos, 2010, p. 471). As a result, corporations are confronted with a multitude of expectations from primary stakeholders, such as company owners, employees, customers, or suppliers, and from secondary stakeholders, such as NGOs or activists, local communities, or governments (Waddock et al., 2002), as well as with pressure from a variety of international institutions (Waddock, 2008). The fact that this simultaneous tendency towards more homogeneity and more heterogeneity is becoming manifest in various local and global expectations creates tensions (Rasche, 2012). Under these conditions, companies seek accepted standards of behaviour (e.g., with respect to sustainability issues), which provide a level playing field, incur the same costs to all companies within an industry, and at the same time provide them with legitimacy (Haack et al., 2012). However, such standards are fragmented and only partially, if at all, available in every industry, every region, or on every sustainability issue (FischerLescano and Teubner, 2004). As a result, MNGs operate under conditions of complexity and may often face highly heterogeneous expectations from their societal and institutional environment (Child and Rodrigues, 2011; Palazzo and Scherer, 2006; Smith and Lewis, 2011).

Under conditions of consistent social expectations and/or widely accepted standards of behaviour, corporations tend to choose adaptation strategies when the costs of organizational change are low and active manipulation strategies when these costs are high. In 
the latter case, corporations engage in decoupling (Boxenbaum and Jonsson, 2008); for example, they attempt to leave the organizational machinery as it is and create a positive public image by simply evoking the impression of complying with established standards, with the help of public relations and manipulation strategies. This way they simply appear legitimate in the eyes of key stakeholders or policy makers (Ashforth and Gibbs, 1990; Barley, 2010) even though their processes have not changed. This tendency is more pronounced when corporations have the power to actively influence their environment (Child and Rodrigues, 2011) and when the societal expectations are not represented within the company - for example, when there are no organizational members that feel responsible for social or environmental issues (Pache and Santos, 2010).

Corporations that employ manipulation strategies do not modify the practices that some of their stakeholders criticize; instead, they manipulate the perception of those stakeholders in order to avoid the pressure. While such strategies of decoupling and impression management are discussed critically in the business and society literature (Palazzo and Richter, 2005; Weaver et al., 1999), it is important to highlight here that they are neither good nor bad in normative terms. As we will argue later on, external demands can be based on unrealistic claims, poor data, or misunderstandings (Teegen et al., 2004) and may often collide with the expectations of other stakeholders (Calton and Payne, 2003; Pache and Santos, 2010). A corporation can apply strategic manipulation or isomorphic adaptation to a wide range of situations in order to maintain its legitimacy. However, both strategies have limitations and may fail under certain conditions. There is always the danger that a corporation's attempts to manipulate perceptions may be uncovered, which may have the opposite effect and damage the corporation's legitimacy (Patriotta et al., 2011).

Even though there is some evidence that strategic manipulation is often successful (Barley, 2010), the cases of Enron (fraudulent book-keeping; Ley Toffler and Reingold, 2003; Time Magazine, 2002), Siemens (widespread corruption; New Tork Times, 2008), or BP (highly risky tactics and a disregard for safety standards; New York Times, 2011) are a reminder that once the image of legitimacy is exposed as a façade, the consequences for companies and top managers in terms of cost and reputation can be disastrous. In all three cases the corporations had created positive public images with the help of public relations (Kaufmann, 2008; Muralidharan et al., 2011; Murphy, 2008). However, as the scandals associated with these corporations have shown, none had actually implemented its publicly announced CSR and sustainability policies by sufficiently changing its corporate structures and practices. These scandals were the result of misconduct by individuals, as well as of systematic problems with incentives and control within the companies. Strategic manipulation and keeping up a façade are more likely to fail when there is anti-corporate action by NGOs and stakeholder activists (den Hond and de Bakker, 2007; Teegen et al., 2004) and when transparency is high and information can be readily disseminated to the relevant public via the media (e.g., the internet or news agencies) (Patriotta et al., 2011).

A strategy of adaptation may also fail if the organization faces many heterogeneous and contradictory expectations (Lamin and Zaheer, 2012). In such cases, adapting to the expectations of one part of the social environment is likely to clash with the expectations of other societal sectors: 'in conflict situations plain compliance is problematic, since 
complying with one demand requires defying the competing other(s)' (Pache and Santos, 2010, p. 463). Palazzo and Scherer (2006) have argued that during the process of globalization the societal environment of multinational firms has become fragmented and heterogeneous and industry standards and self-regulation schemes are often not yet available, but first need to be developed. Under these conditions, adaptation strategies are insufficient for maintaining corporate legitimacy. By contrast, in cases of low consistency of societal expectations, strategic manipulation as well as moral reasoning strategies can be applied selectively to certain stakeholder groups in order to address their legitimacy concerns, by means of either manipulation or argumentation. Manipulation strategies, however, may prove insufficient: the corporation may not be able to actually influence the relevant societal groups in the first place, while the widespread availability of information and communication means that corporate manipulation strategies may be easily discovered and circumvented. Under such conditions moral reasoning will become more important for managing corporate legitimacy (Palazzo and Scherer, 2006).

However, we suggest that moral reasoning cannot completely substitute adaptation and strategic action. The complexity of the corporation's steering task in competitive market societies would overburden the corporation in its strategic course if only moral reasoning was available as a means of establishing legitimacy. Therefore, moral reasoning has to be regarded as a retreat strategy when the mechanisms of social routine, adaptation, and manipulation fail, or as a proactive strategy for establishing relationships of trust with the corporation's constituencies or for addressing emerging sustainability issues that may erode the corporation's legitimacy in the future. Moral reasoning may be appropriate when societal expectations are heterogeneous and corporations engage in moral discourse with particular societal groups in order to selectively address and eventually satisfy their demands (Calton and Payne, 2003). Unlike the adaptation strategy, moral reasoning can be applied selectively to particular stakeholder groups and this will not necessarily lead to a mismatch with the expectations of other groups. However, moral reasoning is costly and requires particular efforts from those who engage in it. Therefore, it cannot entirely substitute social routines, isomorphic adaptation, and strategic manipulation, which often help corporations tackle the legitimacy challenges of competitive environments more efficiently. What is more, in a globalized world the environmental challenges and societal demands to which companies have to respond are in 'continual flux' (Greenwood et al., 2011, p. 319). This means that MNCs are increasingly required to be able to simultaneously apply or to switch between the different legitimacy strategies (i.e., manipulation, adaptation, and moral reasoning) in order to be able to preserve their legitimacy. However, before we get to this issue in detail, we will first illustrate the advantages and limitations of the legitimacy strategies with regard to SD decisions in corporations.

\section{EMPIRIGAL ILLUSTRATION OF LEGITIMAGY STRATEGIES WITH REGARD TO SD ISSUES}

How can corporations react to legitimacy challenges due to sustainability problems? In a highly complex environment, under time pressure, with no acceptable standards of behaviour available, with little or no experience of how to handle the issue at stake and 
confronted with contradictory expectations and aggressive campaigning, it is far from clear which legitimacy strategy is best (Greenwood et al., 2011; Pache and Santos, 2010). The following examples aim to illustrate the contributions and limitations of various legitimacy strategies and to argue in favour of their combination under conditions of complex and heterogeneous environments.

The case of Chiquita Brands International illustrates how strategic manipulation strategies might be successfully employed. Chiquita has been exposed to harsh criticism in the German, Swiss, and Swedish mass media for its cooperation with the Rainforest Alliance. It was argued that the social and environmental standards of this civil society coalition were not sufficiently high. For instance, critics argued that as long as pesticides were used on the plantations, announcements about the reduction of pesticide use were mere window-dressing (DER SPIEGEL, 2006, 2008; Macquet and Kjellberg, 2011). How should the corporation react? On the one hand, Chiquita used to be considered a CSR leader and their partner, the Rainforest Alliance, is an expert NGO that has been working with Chiquita over several years and has also been a key player in various standard-setting, labelling, and monitoring initiatives. On the other hand, the credibility of this engagement and the reputation of the corporation were repeatedly challenged. Here it might make sense to react by adopting a strategic public relations approach if, first, the corporation already employs a credible moral reasoning strategy, second, if the accusations can be refuted, or, third, if the costs of implementing changes are too high (such costs could result, for example, from fulfilling the demand that the company immediately reduces the use of pesticides to zero).

Criticism of a corporation's practices might find broad public support even if it builds on false claims or unrealistic expectations (for example, the idea that a large corporation could switch to a fair trade scheme or phase out a certain pesticide in a couple of weeks). In such a case, corporations might choose to defend their current sustainability engagement against criticism instead of complying with their opponents' demands (Christmann and Taylor, 2002; Oliver, 1991). Critique may not be advanced in a way that it constitutes a concrete alternative option for the corporation: the Chiquita banana has for instance been accused of being less fair than the fair trade banana and less green than the organic banana. Yet, applying fair trade and organic criteria on large plantations might be very difficult, if not impossible from a technical perspective. However, moral reasoning might be chosen as a retreat strategy if the attempt to re-establish corporate credibility by influencing public opinion fails and relevant and powerful actors join the critics. In such a case it might be very risky to carry on using strategic public relations as a means of tackling the situation (Palazzo and Scherer, 2006).

The appropriateness of an isomorphic adaptation strategy is evident in the examples we will discuss below. As mentioned earlier, some companies choose a proactive moral reasoning strategy, which may involve setting and controlling new standards for sustainable supply chain management in cooperation with civil society organizations (Bäckstrand, 2006; Basu and Palazzo, 2008). As soon as a major actor or at least a few actors in an industry take such steps, it makes sense for competitors or other industries to adapt to the emerging institutional context (DiMaggio and Powell, 1983). For instance, while Nike's decision to publish the names of its supply-chain partners was a proactive move that might be interpreted as the result of the company's interaction with civil-society critics, 
the decision of Puma and Adidas to do the same a few days later can be interpreted as an isomorphic adaptation to a new standard (Doorey, 2011). If a new behavioural standard is established that does (or presumably will) meet with broad public acceptance, it might make sense for companies to adapt it to their specific circumstances, instead of going through the long process of devising similar standards with similar partners, which the strategy of moral reasoning would require. Nespresso's (Alvarez et al., 2010) and McDonald's (McDonald's, 2007) decisions to work with the Rainforest Alliance in order to improve the environmental conditions of coffee production in their supply chain can be interpreted as the result of an isomorphic adaptation strategy. The Rainforest Alliance has been working with other MNGs on environmental standards since the early 1990s and has developed a largely accepted (even though not undisputed) set of criteria for sustainable agriculture. If the introduction of standards is costly, this may prevent corporations from adapting to societal demands (Oliver, 1991; Pache and Santos, 2010). However, if the pressure from societal groups is high, corporations may decide to adapt to societal demands despite costs: if these standards become established across an entire industry, the costs of organizational change will be redefined as costs of doing business that apply to all competitors. Again, in such a scenario moral reasoning might be chosen as a retreat strategy if the legitimacy of the standard is disputed or alternative and more credible options emerge.

While the discussion above outlines certain conditions under which manipulation or adaptation strategies might make sense as a first reaction to routine failures, choosing either strategy in reaction to changing expectations and challenged practices clearly has its limits. The following examples illustrate the limitations of the manipulation or adaptation strategies.

The limitations of isomorphic adaptation are obvious in the case of Yahoo (Dann and Haddow, 2008), which can be considered as an instance of the fragmentation of law in the corporate environment (Benvenisti and Downs, 2007). As Fischer-Lescano and Teubner (2004, p. 1004) point out, 'the fragmentation of global law is not simply about legal norm collisions or policy-conflicts, but rather has its origin in contradictions between society-wide institutionalized rationalities, which law cannot solve'. Yahoo has expanded its operations to China. In 2002, Yahoo signed the 'Public pledge on selfdiscipline for the Chinese Internet industry', which is sponsored by the governmentaffiliated Internet Society for China. Together with other internet providers, such as Google and Microsoft, the company was accused of being the gatekeeper for an oppressive government by the Human Rights Watch and other NGOs. In addition, two Chinese journalists were sentenced to ten years in jail because Yahoo disclosed their email addresses to the Chinese government (Brenkert, 2009; Dann and Haddow, 2008). This prompted much criticism, in reaction to which Yahoo argued that the company 'must ensure that its local country sites must operate within the local laws, regulations, and customs' (BBC, 2005). Torn between the expectations of (mainly Western) public audiences and those of the Chinese government, the company chose to adapt to the local rules, thereby not only provoking worldwide indignation, but also triggering a hearing in the US Congress on the complicity of internet companies in human rights violations in China (on complicity, see Wettstein, 2012). Having ignored the moral dimension of its decision to cooperate with local authorities and chosen to adopt routines that are 
approved in other political contexts, the company found itself trapped in a legitimacy crisis. Generally speaking, an isomorphic adaptation strategy may be considered inappropriate in cases of colliding standards that represent conflicting political, cultural, or economic forces (Pache and Santos, 2010).

Likewise, the limitations of strategic manipulation are evident in the case of Wal-Mart: for several years now, Wal-Mart has been under pressure to address the social and environmental side effects of its business practices (Beaver, 2005). The campaign against the company culminated in Robert Greenwald's 2005 documentary entitled 'Wal-Mart: The High Cost of Low Price'. In reaction to the massive criticism, the corporation launched a large-scale advertising campaign aimed at presenting the arguments of its opponents as false and insisted that the public ought to have access to the correct 'facts' (Ethical Corporation, 2005). However, this PR campaign did not solve Wal-Mart's problems but rather contributed to its legitimacy crisis. In response, the company then switched to a retreat strategy, initiating a discourse on environmental questions, such as $\mathrm{CO}_{2}$ emissions, water consumption, or the reduction of waste, with experts critical of its practices and announcing that it would make a $\$ 500$ million investment in greening its supply chain. Recently, Wal-Mart has again been accused of greenwashing, because they have not seriously advanced on implementing their greening strategy, and they have not sufficiently engaged with civil society (Mitchell, 2012). In general, the success of strategic manipulation depends on the ability of the corporation to impose its views on the critics or society at large. Repairing or maintaining legitimacy through strategic manipulation is a high-risk strategy if there is overwhelming evidence in support of the opponents' position or if the opponents' credibility is much higher than that of the corporation. In the case of Wal-Mart, it can be assumed that the corporation chose a strategic manipulation strategy to start with, instead of adapting to societal expectations, in order to avoid the costs of organizational change. However, refusing to adapt to consistent societal expectations can be dangerous and counterproductive for companies.

The above examples provide some empirical evidence that supports our approach developed in the second section of this paper. As explained there, the choice of legitimacy strategy is influenced by two factors: the consistency of environmental expectations and the costs of organizational change. When routines fail, organizations are often expected to change. However, the costs of change can be so high that corporations are more likely to decide to resist external expectations and to attempt to influence key stakeholders through strategic manipulation instead (Oliver, 1991; Pache and Santos, 2010). In contrast, when the costs of change are low, corporations might choose to adapt quickly to expectations if the new standards of behaviour are visible and univocal. In the case of Nike, for instance, the decision to publish its list of suppliers was highly risky because it provided the competitors with information about Nike's partners and this might have affected the corporation's competitiveness. The decision made by Puma and Adidas to follow Nike's example, however, was not as risky. Besides the costs of change, the pressure of external expectations also influences the choice of legitimacy strategies. If those expectations are clear and unambiguous, they promote adaptation. If they are heterogeneous, fragmented, and contradictory, corporations might have a greater incentive to engage in moral reasoning, even if the costs of change seem to be high. High costs of change and low consistency of expectations might favour the choice of strategic 
manipulation or of moral reasoning, if corporations are confronted with legitimacy issues.

In the context of the post-national constellation, corporations have to find answers to the rising tide of legitimacy challenges. This does not mean that they should switch automatically from pragmatic and cognitive to moral legitimacy. Instead, corporations have to develop the necessary sensitivity for identifying the appropriate strategy and the right mix of the three options open to them. The appropriateness of strategic choices with regard to legitimacy might also change over time so that the corporation will sequentially change its legitimacy strategies accordingly. In $t_{1}$, a corporation might decide to develop a solution for a sustainability problem through discussion, while in $t_{2}$, if such a standard is already established and widely accepted, the organization might decide to adapt to the standard without further dialogue (see Figure 1). As a second example, in $\mathrm{t}_{1}$ a corporation might develop an innovative solution for a sustainability challenge (e.g., pioneering the analysis of the life cycle of a specific product) and launch a marketing strategy that centres on this innovation, while in $t_{2}$ it might join a multi-stakeholder initiative and engage in an industry-wide discourse in order to establish the very same innovation as an industry standard. As Child and Rodrigues (2011) have argued, the ability to learn is crucial for companies operating in complex situations.

There may even be a situation where a company is facing a multitude of sustainability issues and contradicting societal expectations simultaneously. Thus, the corporation might be required to manipulate the societal environment, to adapt to social expectations, and to engage in stakeholder dialogues at the same time. The challenge, here, will be to balance the inherent contradictions between these strategies and their organizational prerequisites in order not to lose trust and credibility and, thus, legitimacy. The sports manufacturer Puma, for example, applies all three legitimacy strategies simultaneously in its SD engagement (Baumann-Pauly et al., 2012): (1) For several years now, Puma has applied a moral reasoning strategy by establishing a stakeholder dialogue in which they bring together representatives of the Fair Labor Association, critical NGOs, scientists, and factory managers in order to deliberate on the social and environmental challenges in their supply chain (Roloff, 2008; Steinmann, 2010). If done seriously as a moral reasoning strategy, this means that the views of all parties are open to discourse. (2) At the same time, Puma has also followed an adaptation strategy. As already mentioned, a key concern of NGOs regarding SD is the transparency of the supply chain and when Nike decided to publish its list of suppliers, Puma gave up its resistance against disclosing their suppliers and followed suit. This means that Puma gave up its own views on the issue and just adapted to the external expectations. (3) However, Puma also followed a manipulation strategy. Recently, the company has developed a new and innovative environmental profit and loss account to quantify the true environmental costs of its products and production activities. Realizing that consumers are not overly interested in such sustainability efforts when making their buying decisions, Puma has decided that the transformation of consumer habits should become a key element of their sustainability strategy (Marketingmagazine, 2010). If taken seriously, this means that Puma is sticking to its own views regarding sustainability issues and trying to impose them on their stakeholders. Such simultaneously used legitimacy strategies obviously will create tensions. For instance, a marketing strategy that is meant to educate consumers on 
sustainability might irritate NGOs with whom the company leads a dialogue on worker rights. Such NGOs might perceive the SD performance as not advanced enough to be marketed and they might come under pressure from their own audiences for collaborating with the corporation.

Companies such as Puma must find a way of coping with the conflicts between the different legitimacy strategies when employing them simultaneously in their overarching SD strategy. These contradictions result from the fact that managers who try to combine the three legitimacy strategies at the same time, will have to be open to change their own positions in line with external positions, to defend their positions by imposing them on their stakeholders, and by leaving the resolution between conflicting positions up to open deliberation. As we will argue in the next section, this requires organizations to adopt the so-called 'paradox approach' (Smith and Lewis, 2011) to managing their response strategies.

\section{THE PARADOX OF ACGOMMODATING GONFLICTING LEGITIMAGY STRATEGIES}

The empirical examples presented above demonstrate that all three legitimacy strategies with regard to the corporate contribution to SD have their particular advantages and weaknesses. As the cases illustrate, some strategies seem to work better in certain situations than in others. In view of that, the crucial question for organizations is how to select and to combine the most appropriate legitimacy strategies. In principle, there are three possible approaches to responding to legitimacy demands in complex environments: (1) the 'one best way' approach, (2) the contingency approach, and (3) the paradox approach.

The one best way approach assumes that even though organizations face different situations, there is ultimately one best way of responding to legitimacy threats. Examples of this position can be found in the literature: Ulrich (2008), for instance, maintains that all legitimacy concerns with regard to SD should be dealt with discursively so that consensual solutions can be generated. In particular, corporations should refrain from strategic political action and from manipulating the corporate environment (Ulrich, 2000). A very different example of this 'one best way' approach is the study by Siegel (2009), who seems to regard strategic manipulation as the preferred legitimacy strategy. He argues that corporations should always stress the economic role of the business firm when engaging with green strategies. According to his view, corporations are not directly responsible for advancing the social good, but for being productive and generating profits; it is ultimately up to governmental institutions to develop an appropriate regulatory framework that safeguards the social good (Sundaram and Inkpen, 2004). Corporations maintain their legitimacy by providing economic value to their owners (shareholders) or at least by influencing their perceptions and - indirectly - by contributing to society and sustainable development via the allocation function of markets.

Although attractive due to its simplicity, we would argue that the 'one best way' approach is highly problematic as it has serious shortcomings. First, its premises rest on idealistic assumptions about contextual conditions such as the readiness of organizational members and stakeholders to engage in a constructive discourse, the capacity of 
governmental institutions to set appropriate regulatory frameworks, or the allocation function of markets. Second, the approach tends to overlook the possibility that the envisioned solutions cannot always be realized: the various parties may not always reach consensus nor is it always possible to make the business case for the issue at hand (van den Hove, 2006). Third, the focus on a single legitimacy strategy seems like an unnecessary restriction, given that each of the three strategies has its own strengths and that companies are generally capable of employing more than one strategy. The assumption that corporations can always manipulate public discourse successfully in their favour when their legitimacy is in question is as naïve as assuming that consensus may be reached in any situation of conflict. Overall, the 'one best way' approach does not seem to tap the full potential of legitimacy strategies that corporations have at their disposal.

A more promising approach than the 'one best way' approach is the contingency approach. This approach can also be found in the literature on the management of corporate responses to legitimacy issues (Christmann and Taylor, 2002; Oliver, 1991) or to complex and heterogeneous environments (Child and Rodrigues, 2011; Pache and Santos, 2010; Sirmon et al., 2007). The focus here is on the different strengths and weaknesses of each strategy in relation to different circumstances. The assumption that there is one strategy that fits all situations is refuted. Instead it is argued that, while there is one 'best way' for each situation, this will vary depending on the particular circumstances. Corporations need to identify the one way that best fits a specific situation in order to achieve 'congruence' between the environmental challenge and their strategic response (Hambrick, 1983; Simsek, 2009).

Adapting to the environment in order to create 'an acceptable fit' (Hambrick, 1983; Sirmon et al., 2007, p. 275) and aligning organizational structures and processes to create internal 'harmony' (Sirmon et al., 2007, p. 287) are central to contingency theory. Child and Rodrigues (2011), for example, argue that the choice of strategy in response to environmental demands depends on a corporation's relative power. They suggest that less powerful corporations are limited to a single strategy while more powerful companies have greater choice, but finally focus on only one out of the set of available strategies to deal with environmental complexity. Pache and Santos (2010) suggest that the organizational response depends on two factors: the nature of environmental demands (conflict of goals vs. conflict of means) and the representation of these demands within the organization (whether there is a single representation, multiple representations, or no representation). These authors assume that the environmental contingency factors determine the selection of the response strategy, and that this strategy resolves conflicts and balances heterogeneous demands.

Even though the contingency approach is more sophisticated than the 'one best way' approach, its limitations are apparent in cases characterized by extreme degrees of environmental dynamism, complexity, and heterogeneity of societal demands when corporations are confronted with a multitude of SD issues. Under such conditions it is not possible to assume that there is 'one best way' for any given situation. On the contrary, it is more likely that corporations will continuously need to balance equifinal alternatives that only lead to suboptimal solutions (Gresov and Drazin, 1997). The inherent dynamic of the environment keeps societal demands in 'continual flux' (Greenwood et al., 2011, p. 319), demanding 'flexibility and agile actions' (Simsek, 2009, 
p. 614) from the corporation. This means that a legitimacy strategy may immediately become obsolete and require corporations to respond with 'organizational fluidity' (Schreyögg and Sydow, 2010).

Likewise, if the inherent contradictions in environmental challenges and corporate responses prevail (Gibson and Birkinshaw, 2004), contradiction and conflict may be the rule, rather than the exception, in the process of managing legitimacy. Acknowledging this, Simsek (2009, p. 618) points to the limitations of his own contingency approach as 'new opportunities (and threats) are constantly created by the organization's internal and external dynamics', which means that the organization 'may never achieve a lasting balance'. Moreover, 'there is not just one but many institutional environments' (Scott, 1991, p. 167) with incompatible demands and the corporation has to respond to these by activating different legitimacy strategies at the same time. However, as Greenwood et al. (2011, p. 351) have observed, 'most empirical studies assume or imply that organizations enact single and sustainable responses. In doing so, they largely ignore the fact that "different subunits ... find heterodox ways of responding to the accountability demands of [their] environment" (Binder, 2007, p. 567).'

A direct response to the shortcomings of the contingency approach is the so-called paradox approach. It suggests that organizations can employ different response strategies simultaneously even where these are in conflict with each other, thereby replacing the either/or logic of the contingency approach with a both/and perspective (Lewis, 2000). As various researchers have stressed (e.g., Schreyögg and Sydow, 2010; Smith and Lewis, 2011), organizations are nowadays increasingly faced with a variety of SD issues and conditions (such as high dynamism, heterogeneity, and complexity) where a simple contingency approach requiring organizations to choose between different strategies will no longer suffice. Instead, organizations need to learn to accommodate conflicts between their environmental strategies. As Smith and Lewis write: 'Today, as globalization, innovation, hyper-competition, and social demands create more dynamic and intricate environments, paradox becomes a critical theoretical lens' that can be used 'to ... lead contemporary organizations' (Smith and Lewis, 2011, p. 398). In terms of the three different types of legitimacy strategies, this means that organizations do not choose between different strategies but employ all three strategies at the same time. That is, the organization is simultaneously prepared to defend its own position by trying to impose its views on its critics (strategic manipulation), to uncritically accept the views of its critics (isomorphic adaptation), and also to engage in an honest, open discourse about what course to take (moral reasoning). Employing these three response strategies simultaneously obviously creates internal (and external) tensions and contradictions. Analogous to the case where organizations employ simultaneously strategies of pattern maintenance and of fluidity (Schreyögg and Sydow, 2010) or strategies of knowledge exploitation and of knowledge exploration (Raisch et al., 2009), corporations are faced with the dilemma of both fixing their own points of view as basis for changing the environment (strategic manipulation), of treating their own points of view as flexible and subject to environmental expectations (isomorphic adaptation) or as subject to an open deliberation (moral reasoning). As such, there is no stable point of reference according to which to operate within the organization; the point of reference is both inside, outside, and in the deliberation. Thus, other than in the case of the other two approaches (one-best-way 
approach and contingency approach), the organization has to be able to switch between points of reference without a stable point of reference with which to decide which point of reference to choose (Schreyögg and Sydow, 2010). This obviously presupposes an ability of organizations to master paradoxical tensions.

Of the three approaches to selecting legitimacy strategies presented here, the paradox approach seems to be the most suitable one in the context of the post-national constellation and the corporate contribution to SD (Scherer and Palazzo, 2007, 2011). This does not imply that the insights of the contingency approach are invalid. Instead, the paradox approach can be understood as an extension of the contingency approach, which can be applied in situations where corporations are simultaneously challenged by a multitude of SD issues and environmental demands are characterized by high dynamism, complexity, and heterogeneity (Smith and Lewis, 2011). In this sense, our own framework of legitimacy strategies, discussed in the second section of this paper, incorporates aspects of contingency theory in the description of the advantages that different strategies have in relation to different contextual factors. Yet, in the setting that the post-national constellation describes, corporations will typically have to mix different strategies in order to ensure their sustainability. In contrast to what the contingency approach would suggest, there is no general solution to the problem of strategy selection that can be applied in advance (Lewis, 2000; Smith and Lewis, 2011). Organizations can merely develop the organizational and individual capabilities necessary for activating the various modes of generating legitimacy, and they will have to determine the mix of legitimacy strategies anew for each concrete situation they face (see Greenwood et al., 2011).

Creating the organizational preconditions for activating each of the three legitimacy strategies simultaneously poses a significant challenge for corporations. Corporations that try to develop the ability to activate all three legitimacy strategies simultaneously are typically confronted with the paradox of meeting opposing structural demands. Building on the existing literature on organizational paradoxes, we can distinguish three different ways in which organizations can accommodate the various strategies (Schreyögg and Sydow, 2010): first, structural solutions (Gilbert, 2005; Tushman and O'Reilly, 1996; for overviews, see Greenwood et al., 2011; Raisch and Birkinshaw, 2008); second, contextual solutions (Gibson and Birkinshaw, 2004; Smith and Tushman, 2005; for an overview, see Greenwood et al., 2011; Raisch and Birkinshaw, 2008); third, solutions based on reflection capacities (Schreyögg and Kliesch-Eberl, 2007; Schreyögg and Steinmann, 1987; Schreyögg and Sydow, 2010). These solutions are helpful for understanding how companies can manage different legitimacy strategies. These ideas have not yet been applied to legitimacy issues related to SD.

Structural solutions deal with conflicting organizational functions by means of 'structural separation' (Gibson and Birkinshaw, 2004, p. 210). This entails putting in place a range of structures so that the different units or groups within the organization focus on different functions (Adler et al., 1999; Delmas and Toffler, 2008; Kraatz and Block, 2008; Tushman and O'Reilly, 1996). More precisely, this enables organizations to dedicate different units or groups to different legitimacy strategies. For example, marketing and public relations departments may focus on strategic manipulation (Christensen, 1995), while specialized groups may coordinate an open dialogue with 
stakeholders in the context of a moral reasoning strategy in order to address sustainability issues (Payne and Calton, 2004). At the same time, other groups or units, such as investor relations, may be tightly coupled to specific stakeholders, ensuring the timely recognition of changes in the latter's perceptions and managing the respective adaptation processes within the organization (Lawrence and Lorsch, 1967). In this scenario, each unit or group specializes in a particular legitimacy strategy; thus, it is not exposed to the tensions between the different strategies. However, as critics have pointed out (Gibson and Birkinshaw, 2004; Greenwood et al., 2011), such structural solutions merely shift the tension between the different functional requirements to other levels without resolving the question of how the activities of the various units or groups should be coordinated. As Schreyögg and Sydow (2010, p. 1257) write: 'Strict separation is likely to result in sharp interfaces, ambiguous priorities and a lack of a common orientation' and is thus not sufficient for balancing paradoxical demands.

Contextual solutions, in contrast, create an internal organizational context that encourages individuals to make their own judgments about sustainability issues and about which actions are the most appropriate in a given situation, and also " to do whatever it takes" to deliver results' (Gibson and Birkinshaw, 2004, p. 213). The management of the tension between different requirements is thus shifted to the level of the individual. Contextual solutions require 'ambitextrous leaders . . . who are able to understand, and are sensitive to, the expectations and requirements of constituencies of multiple logics' (Greenwood et al., 2011, p. 356) and who also encourage organizational members to use their own judgment. In terms of organizational design, the only requirement is that the organization must create the appropriate contextual conditions, i.e. discipline, stretch, support, and trust (Raisch and Birkinshaw, 2008) that will help stimulate specific behavioural competences. Thus, this approach allows each individual to decide in each concrete situation whether to apply strategic manipulation, isomorphic adaptation, or moral reasoning in order to address the legitimacy issues involved in the corporation's contribution to SD. However, this solution also has its shortcomings. In particular, it has been pointed out that the focus on the individual 'overstretches the behavioural flexibility of individual members' (Schreyögg and Sydow, 2010, p. 1259). Individuals have their cognitive limits (Raisch et al., 2009) and their behaviour is influenced by organizational routines, so it is unlikely that providing a stimulating context suffices to ensure that the members of the organization select the appropriate response strategies to legitimacy demands.

Developing internal reflection capacities offers another approach to dealing with the paradoxical tensions mentioned above. For this purpose, the corporation creates internal platforms for 'meta-level processes' (Schreyögg and Sydow, 2010, p. 1259). These platforms allow the company to select appropriate response strategies to legitimacy challenges that are linked to the corporation's contribution to sustainability. These meta-level processes might be located on different organizational levels. For example, legitimacy challenges might be initially discussed on the level of the particular subunit in which they have come up; however, if the participants come to the conclusion that the particular challenge and potential responses to it also concern other parts of the organization, the discourse on the topic might be shifted to higher organizational levels that encompass a broader set of organizational members (e.g., representatives of the different parts of the 
organization). This has the advantage of allowing for both direct, localized responses and more coordinated responses among various parts of the organization.

Like the other approaches to managing paradoxical tensions, this approach also has some shortcomings. First, it is probably unrealistic to assume that it would be possible to hold an internal reflective discourse every time a legitimacy challenge related to the corporate involvement with sustainable development arises, given that this would consume a lot of time and resources. Second, this solution presupposes certain elements of the other two solutions: in particular, critical discourse is only possible if there are individuals capable of critical thinking and discussion. These abilities can be encouraged through the creation of a stimulating organizational context, supportive leadership, and appropriate HR policies, such as the selection of open-minded people, personal training in situations of ambiguity and conflict, and incentive systems that endorse reflective critique (see, e.g., Kang and Snell, 2009). Similarly, the selected legitimacy strategies might require specific groups or units that are capable of implementing them. These might include marketing and PR departments whose staff have the necessary skills in strategic manipulation, specialized teams that can provide a platform for an open discourse with stakeholders, or teams that are able to manage the process of change in the case of isomorphic adaptations.

As indicated earlier, the capacity of an organization to accommodate all legitimacy strategies seems to rest on a combination of the three different solutions: the capacity for internal reflection means that the different legitimacy challenges of unsustainable business practices can be considered on different levels of the organization and the selected strategies in response to those challenges can be better coordinated. The contextual solutions approach helps individual members acquire at least a basic ability to select between different legitimacy strategies in direct contact with local stakeholders and their concerns about sustainability issues. This can also help reduce the number of internal reflection platforms that these processes require and encourage individuals to develop the critical ability that is necessary for conducting reflective discussions. Finally, the structural solutions approach can help the organization develop the ability to employ its chosen legitimacy strategies in an effective and efficient way. Seen from this perspective, the corporation will be able to develop a both/and logic in order to respond to the challenges of paradox and to manage the legitimacy expectations with regard to sustainable business practices.

\section{GONGLUSIONS AND GONTRIBUTIONS}

We started this paper with the observation that the debates on sustainable development and on corporate legitimacy have become strongly entangled, in the sense that corporations that do not conform to expectations about sustainability will see their legitimacy challenged. Drawing on the existing literature, we have argued that the opportunity to tackle perceived legitimacy challenges is what mainly motivates corporations to adopt sustainable practices and engage in debates on SD issues. The traditional approach to such challenges entails either adapting isomorphically to the expectations of the external stakeholders or strategically manipulating those expectations without altering the corporation's existing structures and practices. However, we argued that it is no longer sufficient for MNCs to rely on these two legitimacy strategies due to the growing 
complexity and heterogeneity of today's social environment (Child and Rodrigues, 201 1; Jones and Fleming, 2003; Kostova and Zaheer, 1999; Scherer and Palazzo, 201 1; Smith and Lewis, 2011). Instead, corporations are increasingly acknowledging the necessity of moral reasoning as an alternative legitimacy strategy (Palazzo and Scherer, 2006) and also the need to develop the capacity to activate all three legitimacy strategies simultaneously, if necessary. We showed that both the 'one best way' approach (e.g., Ulrich, 2000) and the contingency approach (e.g., Child and Rodrigues, 2011) with their focus on a single legitimacy strategy (in general or for each situation) are problematic as corporations navigate in an increasingly fragmented and dynamic global environment facing multiple, heterogeneous, and conflicting SD-related challenges. In such contexts, the successful maintenance and repair of legitimacy tends to require a much more sophisticated approach that calls for a capacity to combine all three strategies in order to address the various legitimacy issues related to the corporation's contribution to SD. Drawing on the burgeoning paradox literature (Raisch and Birkinshaw, 2008; Schreyögg and Sydow, 2010; Smith and Lewis, 2011), we described how corporations can develop such a capacity by combining structural and contextual arrangements with internal platforms for reflection. We argue that corporations that possess this capacity are more successful in preserving their legitimacy in the face of multiple, heterogeneous, and conflicting SD-related challenges than those that do not. In our paper we thus evaluate the appropriateness of the different legitimacy strategies, with regard to particular issues in particular situations, from a corporate perspective. Our concept can also be used with a different epistemological lens. Those strategies (and their combinations) can be examined as appropriate or inappropriate from a normative point of view as well. However, such a normative-ethical analysis of the application of alternative legitimacy strategies is beyond the scope of this paper.

Overall, this paper makes contributions to two streams of literature. First, it contributes to the burgeoning SD literature by providing a systematic analysis of SD-related issues from the perspective of corporate legitimacy. While other authors have already pointed to the fruitfulness of the institutional perspective for studying how corporations deal with SD-related issues (Bansal, 2005; Delmas and Montes-Sancho, 2011; Jennings and Zandbergen, 1995; Schaefer, 2007), this is the first paper to provide a systematic analysis of the different legitimacy strategies that are connected to SD. Thus, we contribute to this literature by providing an integrated framework of the different legitimacy strategies and the ways in which they are employed. Beyond that, we make a further contribution to the SD debate by elaborating on the challenges resulting particularly from operations in increasingly fragmented and dynamically globalized environments, which require a 'paradox approach' for managing SD-related legitimacy concerns. As Marcus and Fremeth (2009) have argued, SD will be a key challenge for companies and managers not because it offers an additional potential to make profits but because it becomes a taken for granted assumption of western societies that corporations invest in green management. Put differently, it becomes a key dimension of legitimacy. This does create tensions within corporations and between corporations and their respective societal contexts in global business. Research has to explore how these tensions can be managed, which competencies have to be built up, and how SD, as a public good, can be aligned with business objectives (Marcus and Fremeth, 2009). Our paper analyses 
these tensions and develops insights into the organizational implications of managing legitimacy and the corporate engagement with SD. Second, we contribute to the institutional literature, which lately has called for more research on organizational responses to institutional complexity (Kostova and Zaheer, 1999; Kraatz and Block, 2008; Lamin and Zaheer, 2012). Greenwood et al. (2011, p. 351), in particular, note that the 'sustainability of organizational responses and their alteration and variability across time is a neglected but important theme that deserves serious attention'. Pache and Santos (2010, p. 473) have already shown that organizations that are 'particularly competent in mobilizing [different response] strategies are likely to be in a better position to survive and thrive in the mist of conflicting institutional demands'. However, they did not explore this issue further and underestimate the dynamics of environmental challenges, regarding conflict and heterogeneity among institutional demands as an exception rather than the rule in the globalized world (see the limitations in Pache and Santos, 2010, p. 472).

In our paper, we show that the integration of concepts from the paradox literature can help explain how organizations are able to respond to contradictory legitimacy demands by employing conflicting strategies in parallel, which implies a 'both/and perspective' instead of an 'either/or choice' (Smith and Lewis, 2011, p. 387). In this way we have opened up new avenues for institutional research. In particular, further research might now examine empirically whether organizations in heterogeneous and dynamic environments that have chosen a paradox approach are indeed more successful in preserving their overall legitimacy than those that have chosen other approaches. In addition to that, further research might look into the different ways in which the paradox approach to managing legitimacy challenges is accomplished by different organizations, explore how organizations maintain their identity despite the heterogeneity of legitimacy strategies, and analyse how this affects the overall success of their responses.

\section{ACKNOWLEDGMENTS}

We thank the editors of the $\mathcal{F} M S$ special issue for their helpful comments during the development of this paper. An early version of this paper was presented at the 'Foundations of Sustainability - An International Conference' sponsored by the Fournal of Management Studies and the Society for the Advancement of Management Studies (Loughborough, UK, 27-29 September 2010). We have benefited from comments by Dorothée Baumann-Pauly, Patrick Haack, Sebastian Raisch, Andreas Rasche, Dennis Schoeneborn, Georg Schreyögg, and Douglas Schuler, and from discussions at research seminars and conferences. We thank Artemis Gause (London) and Ann Nelson (Zurich) for their help with the English language. Andreas Georg Scherer and Guido Palazzo acknowledge the support by the Swiss National Science Foundation for the project 'Corporate Legitimacy and Corporate Communication - A Meso Level Analysis of Organizational Structures within Global Business Firms' (Projekt no. 100014_129995). Andreas Georg Scherer acknowledges the support by the Swiss National Science Foundation under a grant to the National Centre of Competence in Research on Trade Regulation, based at the World Trade Institute of the University of Bern, Switzerland.

\section{REFERENCES}

Adler, P. S., Goldoftas, B. and Levine, D. I. (1999). 'Flexibility versus efficiency: a case study of model changeovers in the Toyota production system'. Organization Science, 10, 43-68.

Alvarez, G., Pilbeam, C. and Wilding, R. (2010). 'Nestlé Nespresso AAA sustainable quality program: an investigation into the governance dynamics in a multi-stakeholder supply chain network'. Supply Chain Management: An International Fournal, 15, 165-82. 
Ashforth, B. E. and Gibbs, B. W. (1990). 'The double-edge of organizational legitimation'. Organization Science, 1, 177-94.

Bäckstrand, K. (2006). 'Multi-stakeholder partnerships for sustainable development: rethinking legitimacy, accountability and efficiency'. European Environment, 16, 290-306.

Bansal, P. (2002). 'The corporate challenges of sustainable development'. Academy of Management Executive, 16, $122-31$.

Bansal, P. (2005). 'Evolving sustainability: a longitudinal study of corporate sustainability development'. Strategic Management Fournal, 26, 197-218.

Barley, S. R. (2010). 'Building an institutional field to corral a government: a case to set an agenda for organizational studies'. Organization Studies, 31, 777-805.

Barney, J. B. (1991). 'Firm resources and sustained competitive advantage'. Fournal of Management, 17, 99-120.

Basu, K. and Palazzo, G. (2008). 'Corporate social responsibility: a process model of sensemaking'. Academy of Management Review, 33, 122-36.

Baumann-Pauly, D., Scherer, A. G. and Palazzo, G. (2012). Navigating through Paradoxical Stakeholder Expectations: Organizational Implications of Managing Corporate Legitimacy in Complex Environments. University of Zurich, UZH Business Working Paper No. 321.

BBC (2005). Tahoo helped jail China writer. Available at: http://news.bbc.co.uk/2/hi/4221538.stm (accessed 22 January 2013).

Beaver, W. (2005). 'Battling Wal Mart: how communities can respond'. Business and Society Reviere, 110, 159-69.

Beck, U. (2000). What is Globalization? Cambridge: Polity Press.

Beck-Gernsheim, E. and Beck, U. (2002). Individualization: Institutionalized Individualism and Its Social and Political Consequences. London: Sage.

Bednarek, R. S. (2011). Strategizing for Legitimacy in Pluralistic Contexts: New Zealand's Science Sector. PhD Thesis, Victoria University Wellington.

Benvenisti, E. and Downs, G. W. (2007). 'The empire's new clothes: political economy and the fragmentation of international law'. Stanford Law Review, 60, 595-632.

Binder, A. (2007). 'For love and money: organizations' creative responses to multiple environmental logics'. Theory and Society, 36, 547-71.

Boxenbaum, E. and Jonsson, S. (2008). 'Isomorphism, diffusion and decoupling'. In Greenwood, R., Oliver, C., Sahlin, K. and Suddaby, R. (Eds), The Sage Handbook of Organizational Institutionalism. London: Sage, $78-98$.

Brenkert, G. (2009). 'Google, human rights and moral compromise'. Fournal of Business Ethics, 85, 453-78.

Brunsson, N., Rasche, A. and Seidl, D. (2012). 'The dynamics of standardization: three perspectives on standards in organization studies'. Organization Studies, 33, 613-32.

Buckley, P. J. and Ghauri, P. N. (2004). 'Globalisation, economic geography and the strategy of multinational enterprises'. Fournal of International Business Studies, 35, 81-98.

Calton, J. M. and Payne, S. L. (2003). 'Coping with paradox'. Business and Society, 42, 7-42.

Chandler, A. D. and Mazlish, B. (Eds) (2005). Leviathans: Multinational Corporations and the New Global History. Cambridge: Cambridge University Press.

Child, J. and Rodrigues, S. B. (2011). 'How organizations engage with external complexity: a political action perspective'. Organization Studies, 32, 803-24.

Christensen, L. T. (1995). 'Buffering organizational identity in the marketing culture'. Organization Studies, 16, $651-72$.

Christmann, P. (2000). 'Effects of "best practices" of environmental management on cost advantage: the role of complementary assets'. Academy of Management Fournal, 43, 663-80.

Christmann, P. and Taylor, G. (2002). 'Globalization and the environment: strategies for international voluntary environmental initiatives'. Academy of Management Executive, 16, 121-35.

Cutler, A. C. (2001). 'Critical reflections on the Westphalian assumptions of international law and organization: a crisis of legitimacy'. Review of International Studies, 27, 133-50.

Dann, G. E. and Haddow, N. (2008). 'Just doing business or doing just business: Google, Microsoft, Yahoo! and the business of censoring China's internet'. Fournal of Business Ethics, 79, 219-34.

Deephouse, D. L. (1996). 'Does isomorphism legitimate?'. Academy of Management fournal, 39, 1024-39.

Delmas, M. A. (2002). 'The diffusion of environmental management standards in Europe and in the United States: an institutional perspective'. Policy Sciences, 35, 91-119.

Delmas, M. A. and Montes-Sancho, M. J. (2011). 'An institutional perspective of the diffusion of international management system standards: the case of the environmental management standard 14001'. Business Ethics Quarterly, 21, 103-32. 
Delmas, M. A. and Toffler, M. W. (2008). 'Organizational responses to environmental demands: opening the black box'. Strategic Management Fournal, 29, 1027-55.

den Hond, F. and de Bakker, F. G. A. (2007). 'Ideologically motivated activism: how activist groups influence corporate social change activities'. Academy of Management Review, 32, 901-24.

DER SPIEGEL (2006). 'Meister der Verdrehung', 60, 31, 72-76.

DER SPIEGEL (2008). 'Das grosse Moralmonopoly', 62, 19, 102-03.

DiMaggio, P. J. and Powell, W. W. (1983). 'The iron cage revisited: institutional isomorphism and collective rationality in organizational fields'. American Sociological Reviere, 48, 147-60.

Doorey, D. J. (2011). 'The transparent supply chain: from resistance to implementation at Nike and Levi-Strauss'. Fournal of Business Ethics, 103, 587-603.

Ethical Corporation (2005). 'Watching Wal-Mart', May, 16-17.

Fischer-Lescano, A. and Teubner, G. (2004). 'Regime-collisions: the vain search for legal unity in the fragmentation of global law'. Michigan fournal of International Law, 25, 999-1046.

Fombrun, C. J. (2001). 'Corporate reputations as economic assets'. In Hitt, M. A., Freeman, R. E. and Harrison, J. S. (Eds), The Blackwell Handbook of Strategic Management. Oxford: Blackwell, 289312.

Gibson, C. B. and Birkinshaw, J. (2004). 'The antecedents, consequences, and mediating role of organizational ambidexterity'. Academy of Management Fournal, 47, 209-26.

Gilbert, C. (2005). 'Unbundling the structure of inertia: resource versus routine rigidity'. Academy of Management fournal, 48, 741-63.

Gilbert, D. U., Rasche, A. and Waddock, S. (2011). 'Accountability in a global economy. The emergence of international accounting standards'. Business Ethics Quarterly, 21, 23-44.

Greenwood, R., Raynard, M., Kodeih, F., Micoletta, E. R. and Lounsbury, M. (2011). 'Institutional complexity and organizational response'. Academy of Management Annals, 5, 317-71.

Gresov, C. and Drazin, R. (1997). 'Equifinality: functional equivalence in organization design'. Academy of Management Reviere, 22, 409-28.

Haack, P., Schoeneborn, D. and Wickert, C. (2012). 'Talking the talk, moral entrapment, creeping commitment? Exploring narrative dynamics in corporate responsibility standardization'. Organization Studies, $\mathbf{5 / 6}, 815-45$.

Habermas, J. (1990). 'Discourse ethics: notes on a program of philosophical justification'. In Habermas, J. (Ed.), Moral Consciousness and Communicative Action. Cambridge, MA: MIT Press, 43-115.

Habermas, J. (2001). The Postnational Constellation. Cambridge, MA: MIT Press.

Hambrick, D. C. (1983). 'Some tests of the effectiveness and functional attributes of Miles and Snow's strategic types'. Academy of Management Fournal, 26, 5-26.

Hart, S. L. (1995). 'A natural-resource-based view of the firm'. Academy of Management Review, 37, 9861014.

Hedstrom, G., Poltorzycki, S. and Stroh, P. (1998). 'Sustainable development: the next generation of business opportunity'. Prism, 9, 4, 1-19.

Hillman, A. J., Keim, G. and Schuler, D. (2004). 'Corporate political activity: a review and research agenda'. Journal of Management, 30, 837-57.

Jennings, P. D. and Zandbergen, P. A. (1995). 'Ecologically sustainable organizations: an institutional approach'. Academy of Management Review, 20, 1015-52.

Jones, T. M. and Fleming, P. (2003). 'Unpacking complexity through critical stakeholder analysis: the case of globalization'. Business and Society, 42, 430-54.

Kang, S. and Snell, S. A. (2009). 'Intellectual capital architectures and ambidextrous learning: a framework for human resource management'. Fournal of Management Studies, 46, 65-92.

Kaufmann, D. (2008). Siemens and the Illusion of CSR and Codes of Business Integrity. Available at: http:// thekaufmannpost.net/siemens-and-the-illusion-of-csr-and-corporate-integrity/ (accessed 8 December 2011).

Kaul, I., Conceição, P., Le Goulven, K. and Mendoza, R. U. (Eds) (2003). Providing Global Public Goods. Oxford: Oxford University Press.

Kobrin, S. J. (2001). 'Sovereignty@bay: globalization, multinational enterprise, and the international political system'. In Rugman, A. M. and Brewer, T. L. (Eds), The Oxford Handbook of International Business. New York: Oxford University Press, 181-205.

Kobrin, S. J. (2009). 'Private political authority and public responsibility: transnational politics, transnational firms and human rights'. Business Ethics Quarterly, 19, 349-74.

Kostova, T. and Zaheer, S. (1999). 'Organizational legitimacy under conditions of complexity: the case of the multinational enterprise'. Academy of Management Review, 24, 64-81. 
Kraatz, M. and Block, E. (2008). 'Organizational implications of institutional pluralism'. In Greenwood, R., Oliver, C., Sahlin, K. and Suddaby, R. (Eds), The Sage Handbook of Organizational Institutionalism. London: Sage, 243-75.

Lamin, A. and Zaheer, S. (2012). 'Wall Street vs. main street: firm strategies for defending legitimacy and their impact on different stakeholders'. Organization Science, 23, 47-66.

Lawrence, P. and Lorsch, J. (1967). 'Differentiation and integration in complex organizations'. Administrative Science Quarterly, 12, 1-30.

Lewis, M. (2000). 'Exploring paradox: toward a more comprehensive guide'. Academy of Management Review, 25, 760-76.

Ley Toffler, B. and Reingold, J. (2003). Final Accounting: Ambition, Greed and the Fall of Arthur Andersen. New York: Broadway.

Macquet, M. and Kjellberg, H. (2011). The Struggle over the Character of Responsible Bananas. Working Paper, Stockholm School of Economics.

Marcus, A. A. and Fremeth, A. R. (2009). 'Green management matters regardless'. Academy of Management Perspectives, 23, 17-26.

Marketingmagazine (2010). Puma Chief Aims to Spread Social Awareness to Consumers. Available at: http:// www.marketingmagazine.co.uk/news/1027765/Puma-chief-aims-spread-social-awareness-consumers/ (accessed 15 September 2010).

Mathews, J. T. (1997). 'Power shift'. Foreign Affairs, 76, 50-66.

McDonald's (2007). McDonald's Coffee Takes Sustainability Mainstream by Committing to Eco-Friendly Farmers. Available at: http://www.mcdpressoffice.eu/pressreleases/pressreleases_2007_ql.php (Press release by McDonalds UK; accessed 22 January 2013).

McWilliams, A. and Siegel, D. (2001). 'Corporate social responsibility: a theory of the firm perspective'. Academy of Management Review, 26, 117-27.

McWilliams, A., Siegel, D. S. and Wright, P. M. (2006). 'Corporate social responsibility: strategic implications'. Fournal of Management Studies, 43, 1-18.

Mena, S. and Palazzo, G. (2012). 'Input and output legitimacy of multi-stakeholder initiatives'. Business Ethics Quarterly, 22, 527-56.

Meyer, J. W. and Rowan, B. (1977). 'Institutionalized organizations: formal structure as myth and ceremony'. American Fournal of Sociology, 83, 340-63.

Mitchell, R. K., Agle, B. R. and Wood, D. J. (1997). 'Toward a theory of stakeholder identification and salience: defining the principle of who and what really counts'. Academy of Management Review, 22, 853-86.

Mitchell, S. (2012). Walmart's Promised Green Product Rankings Fall Off the Radar. Available at: http://grist.org/ business-technology/2011-11-21-walmart-promised-green-product-rankings-fall-off-radar/ (accessed 16 May 2012).

Muralidharan, S., Dillstone, K. and Shin,J. H. (2011). 'The gulf coast oil spill: extending the theory of image restoration discourse to the realm of social media and beyond petroleum'. Public Relations Review, 37, 226-32.

Murphy, R. (2008). Enron, the CSR Poster Child. Available at: http://townhall.com/columnists/ robertmurphy/2008/04/26/enron,_the_csr_poster_child/page/full/ (accessed 8 December 2011).

New York Times (2008). Siemens to Pay \$1.34 Billion in Fines. Available at: http://www.nytimes.com/2008/12/ 16/business/worldbusiness/16siemens.html (accessed 8 December 2011).

New York Times (2011). BP Shortcuts Led to Gulf Oil Spill, Report Says. Available at: http://www.nytimes.com/ 2011/09/15/science/earth/15spill.html (accessed 8 December2011).

Oliver, C. (1991). 'Strategic responses to institutional processes'. Academy of Management Revierw, 16, 145-70.

Orlitzky, M., Siegel, D. S. and Waldman, D. A. (2011). 'Strategic corporate social responsibility and environmental sustainability'. Business and Society, 50, 6-27.

Pache, A.-C. and Santos, F. (2010). 'When worlds collide: the internal dynamics of organizational responses to conflicting institutional demands'. Academy of Management Review, 35, 455-76.

Palazzo, G. and Richter, U. (2005). 'CSR business as usual? The case of the tobacco industry'. Fournal of Business Ethics, 61, 387-401.

Palazzo, G. and Scherer, A. G. (2006). 'Corporate legitimacy as deliberation: a communicative framework'. Fournal of Business Ethics, 66, 71-88.

Patriotta, G., Gond, J. and Schultz, F. (2011). 'Maintaining legitimacy: controversies, orders of worth, and public justifications'. Fournal of Management Studies, 48, 1804-36.

Payne, S. and Calton, J. (2004). 'Exploring research potentials and applications for multi-stakeholder learning dialogues'. Fournal of Business Ethics, 55, 71-78. 
Pfeffer, J. and Salancik, G. (1978). The External Control of Organizations: A Resource Dependence Perspective. New York: Harper and Row.

Poole, M. S. and Van de Ven, A. H. (1989). 'Using paradox to build management and organization theories'. Academy of Management Review, 14, 562-78.

Porter, M. E. and Kramer, M. R. (2011). 'Creating shared value'. Harvard Business Review, 89, 62-77.

Powell, W. W. and DiMaggio, P. J. (Eds) (1991). The New Institutionalism in Organizational Analysis. Chicago, IL: University of Chicago Press.

Raisch, S. and Birkinshaw, J. (2008). 'Organizational ambidexterity: antecedents, outcomes, and moderators'. Fournal of Management, 34, 375-409.

Raisch, S., Birkinshaw, J., Probst, G. and Tushman, M. L. (2009). 'Organizational ambidexterity: balancing exploitation and exploration for sustained performance'. Organization Science, 20, 685-95.

Rasche, A. (2012). 'Global policies and local practice: lose and tight couplings in multi-stakeholder initiatives'. Business Ethics Quarterly, 22, 679-708.

Rockström, J., Steffen, W., Noone, K., Persson, A., Chapin, F. S. III, Lambin, E. F., et al. (2009). 'A safe operating space for humanity'. Nature, 461, 472-75.

Roloff, J. (2008). 'A life cycle model of multi-stakeholder networks'. Business Ethics: A European Reviewe, 17, $311-25$.

Schaefer, A. (2007). 'Contrasting institutional and performance accounts of environmental management systems: three case studies in the UK water and sewerage industry'. Fournal of Management Studies, 44, 506-35.

Scherer, A. G. and Palazzo, G. (2007). 'Toward a political conception of corporate responsibility: business and society seen from a Habermasian perspective'. Academy of Management Review, 32, 1096-120.

Scherer, A. G. and Palazzo, G. (2011). 'The new political role of business in a globalized world: a review of a new perspective on CSR and its implications for the firm, governance, and democracy'. Fournal of Management Studies, 48, 899-931.

Schreyögg, G. and Kliesch-Eberl, M. (2007). 'How dynamic can organizational capabilities be? Towards a dual-process model of capability dynamization'. Strategic Management Fournal, 28, 913-33.

Schreyögg, G. and Steinmann, H. (1987). 'Strategic control: a new perspective'. Academy of Management Reviewe, 12, 91-103.

Schreyögg, G. and Sydow, J. (2010). 'Organizing for fluidity? Dilemmas of organizational forms'. Organization Science, 21, 1251-62.

Scott, W. R. (1991). 'Unpacking institutional arguments'. In Powell, W. W. and DiMaggio, P. J. (Eds), The New Institutionalism in Organizational Analysis. Chicago, IL: University of Chicago Press, 164-82.

Shelton, D. (Ed.) (2000). Commitment and Compliance: The Role of Non-Binding Norms in the International Legal System. Cambridge: Cambridge University Press.

Shrivastava, P. (1995). 'Environmental technologies and competitive advantage'. Strategic Management Fournal, 16, Special Issue Summer, 183-200.

Siegel, D. S. (2009). 'Green management matters only if it yields more green: an economic/strategic perspective'. Academy of Management Perspectives, 23, 5-16.

Simsek, Z. (2009). 'Organizational ambidexterity: towards a multilevel understanding'. Fournal of Management Studies, 46, 597-624.

Sirmon, D. G., Hitt, M. A. and Ireland, R. D. (2007). 'Managing firm resources in dynamic environments to create value: looking inside the black box'. Academy of Management Review, 32, 273-393.

Smith, W. K. and Lewis, M. W. (2011). 'Toward a theory of paradox: a dynamic model of organizing'. Academy of Management Review, 36, 381-403.

Smith, W. K. and Tushman, M. L. (2005). 'Managing strategic contradictions: a top management model for managing innovation streams'. Organization Science, 16, 522-36.

Springle, G. B. and Maines, L. A. (2010). 'The benefits and costs of corporate social responsibility'. Business Horizons, 53, 445-53.

Steinmann, H. (2010). 'Corporate ethics and business practice: reflections on the PUMA case'. Annual Review of Law and Ethics, 18, 431-46.

Suchman, M. C. (1995). 'Managing legitimacy: strategic and institutional approaches'. Academy of Management Revierw, 20, 571-610.

Sundaram, A. K. and Inkpen, A. C. (2004). 'The corporate objective revisited'. Organization Science, 15, 350-63.

Teegen, H., Doh, J. P. and Vachani, S. (2004). 'The importance of nongovernmental organizations in global governance and value creation: an international business research agenda'. Fournal of International Business Studies, 35, 463-83. 
Time Magazine (2002). Enron: Who's Accountable? Available at: http://www.time.com/time/magazine/article/ 0,9171,1001636,00.html (accessed 8 December 2011).

Tushman, M. L. and O'Reilly, C. A. (1996). 'Ambidextrous organizations: managing evolutionary and revolutionary change'. California Management Review, 38, 8-30.

Ulrich, P. (2000). 'Integrative Economic ethics - towards a conception of socio-economic rationality'. In Koslowski, P. (Ed.), Contemporary Economic Ethics and Business Ethics. Berlin: Springer, 37-54.

Ulrich, P. (2008). Integrative Economic Ethics: Foundations of a Civilized Market Economy. Cambridge: Cambridge University Press.

United Nations (1987). Report of the World Commission on Environment and Development. General Assembly Resolution 42/187, 11 December 1987. Available at: http://www.un.org/documents/ga/res/42/ ares42-187.htm (accessed 14 October 2011).

Van den Hove, S. (2006). 'Between consensus and compromise: acknowledging the negotiation dimension in participatory approaches'. Land Use Policy, 23, 10-17.

Waddock, S. A. (2008). 'Building a new infrastructure for corporate responsibility'. Academy of Management Perspectives, 22, 87-108.

Waddock, S. A., Bodwell, C. and Graves, A. B. (2002). 'Responsibility: the new business imperative'. Academy of Management Executive, 16, 132-48.

WBCSD (2012). World Business Council for Sustainable Development. Business solutions for a sustainable world. Annual review report 2011/2012. Available at: http://www.wbcsd.org/annual-review/annualreview.aspx/ (accessed 22 January 2013).

Weaver, G. R., Treviño, L. K. and Cochran, P. L. (1999). 'Integrated and decoupled corporate social performance: management values, external pressures, and corporate ethics practices'. Academy of Management Fournal, 42, 539-52.

Wettstein, F. (2012). 'Silence as complicity: elements of a corporate duty to speak out against the violation of human rights'. Business Ethics Quarterly, 22, 37-61.

WWF (2012). Living Planet. Report 2012. Available at: http://wwf.panda.org/about_our_earth/ all_publications/living_planet_report/ (accessed 16 May 2012). 